\title{
Vegetation dynamics from annually burning tallgrass prairie in different seasons
}

\author{
E. GENE TOWNE AND KEN E. KEMP
}

Authors are Research Associate, Division of Biology (egtowne@ksu.edu), and Professor, Department of Statistics, Kansas State University, Manhattan, Kans. 66506-4901

\begin{abstract}
Traditional perception of how tallgrass prairie responds to fire at times other than late spring is either anecdotal or extrapolated from studies that lack spatial or temporal variability. Therefore, we evaluated patterns of change in vegetation cover, species richness, diversity, and aboveground biomass production on 2 different topographic positions from ungrazed watersheds that were burned annually for 8 years in either autumn (November), winter (February), or spring (April). Topoedaphic factors influenced the response patterns of some species to seasonal fire, although differences were primarily in the rate of change. Annual burning in autumn and winter produced similar trends through time for most species. Big bluestem (Andropogon gerardii Vitman) cover increased with all burn regimes, whereas indiangrass [Sorghastrum nutans (L.) Nash] increased only with spring burning. Repeated autumn and winter burning eventually increased perennial forb cover, with the largest increases occurring in heath aster [Symphyotrichum ericoides (L.) Nesom], aromatic aster [S. oblognifolium (Nutt.) Nesom], tall goldenrod (Solidago canadensis $\mathbf{L}$.), and legumes. Species richness increased $(\mathrm{P}<$ 0.001) through time with spring and winter burning, but was similar among all burn treatments after 8 years of annual fire. Average grass and forb biomass did not differ among burn seasons on either topographic position, although interannual biomass production fluctuated inconsistently with time of burn. Our findings contrast with many of the conventional views of how tallgrass prairie vegetation responds to seasonal fire and challenges traditional recommendations that burning should only occur in late spring.
\end{abstract}

Key Words: burn season, fire ecology, grassland vegetation

Fire is an integral component of prairie development (Axelrod 1985 ), and for more than 7,000 years vegetation patterns have been influenced by anthropogenic burning practices (Sauer 1944, Stewart 1951, Woodcock and Wells 1994, Kimmerer and Lake 2001). Although presettlement prairie fires potentially could

Earlier drafts of this manuscript were improved by comments from David Hartnett and John Blair. We also thank Amanda Kuhl and the LTER clipping crew for the biomass collections. Konza Prairie Biological Station is a preserve of The Nature Conservancy managed by the Division of Biology at Kansas State University. The National Science Foundation Long-Term Ecological Research Program and the Kansas Agricultural Experiment Station provided support for this project. This paper is contribution No. 02-263-J from the Kansas Agricultural Experiment Station

Manuscript accepted 2 Jul. 02.
Resumen

La percepción tradicional de como la pradera de zacates altos responde al fuego en tiempos distintos a fines de primavera es anecdótica $o$ extrapolada de estudios que carecen de variabilidad espacial y temporal. Por lo tanto, nosotros evaluamos los patrones de cambio en la cobertura vegetal, riqueza de especies, diversidad y producción de biomasa en 2 posiciones topográficas diferentes de cuencas hidrológicas sin apacentamiento que fueron quemadas anualmente por 8 años tanto en otoño (Noviembre), invierno (Febrero) o primavera (Abril). Los factores topoedáficos influenciaron los patrones de respuesta de algunas especies al fuego estacional, aunque las diferencias fueron principalmente en la tasa de cambio. La quema anual en otoño e invierno produjo tendencias similares a través del tiempo para la mayoría de las especies. La cobertura de "Big bluestem" (Andropogon gerardii Vitman) se incrementó con todos los regímenes de quema mientras que la del "Indiangrass" [Sorghastrum nutans (L.) Nash] se incrementó solo con la quema de primavera.. Las quemas repetidas en otoño e invierno eventualmente aumentaron la cobertura de hierbas perennes y el mayor aumento ocurrió en "Heath aster" [Symphyotrichum ericoides (L.) Nesom], "Aromatic aster" [S. oblognifolium (Nutt.) Nesom], "Tall goldenrod" (Solidago canadensis L.) y leguminosas. La riqueza de especies se incrementó $(P<0.001)$ a través del tiempo con las quemas de primavera e invierno, pero después de 8 años de quemas anuales fue similar en todos los tratamientos de quema. La biomasa promedio de zacates y hierbas no difirió entre las épocas de quema en cualquiera de las posiciones topográficas, aunque la producción interanual de biomasa fluctuó inconsistentemente con el tiempo de quema. Nuestros hallazgos contrastan con muchos de los puntos de vista convencionales de como la vegetación de las praderas de zacates altos responde al fuego estacional y reta a las recomendaciones tradicionales de que la quema debe ocurrir solo a fines de primavera.

occur at any time of the year (Bragg 1982), intentional burning in autumn and late winter was a frequent ritual of most native American tribes (Catlin 1973, Pyne 1982, McClain and Elzinga 1994). Prairie fires were suppressed during European settlement, and accidental or lightning-caused wildfires were the primary source of burning (Hoy 1989, McClain and Elzinga 1994). After the influx of transient cattle to the Kansas Flint Hills in the late 1800 's, however, the incentive for prairie burning renewed and pastures were ignited annually in February or March to improve livestock gains (Kollmorgen and Simonett 1965, Isern 1985). Traditional burn season shifted gradually to mid- or late-April, 
because fire at that time favored the warmseason perennial grasses that are the mainstay of livestock grazing (McMurphy and Anderson 1965, Anderson et al. 1970). In addition, burning Kansas tallgrass prairie at times other than late spring has been staunchly discouraged because of reputed adverse effects on vegetation composition and productivity (Hanks and Anderson 1957, Anderson 1961, 1965, McMurphy and Anderson 1963, 1965, Owensby and Anderson 1967, Anderson et al. 1970).

The impetus of fire research in tallgrass prairie has focused on the vegetation responses imposed by fire frequency, with the burns occurring in April (Abrams and Hulbert 1987, Gibson and Hulbert 1987, Gibson 1988, Collins 1992). Perceptions of how tallgrass prairie responds to autumn or winter fires are derived either from small plots (Aldous 1934, McMurphy and Anderson 1963, 1965, Bragg 1982, Lovell et al. 1982, Towne and Owensby 1984), or from single burn events (Penfound and Kelting 1950, Kelting 1957, Adams and Anderson 1978, Adams et al. 1982). Topographic position, soil texture, and climatic factors, however, can affect how plants respond to fire (Abrams and Hulbert 1987, Gibson and Hulbert 1987), and documentation of spatial and temporal trends from repeated seasonal burning is lacking. Additionally, diversity indices and the response of most subdominant species to seasonal fire are anecdotal or speculative. Understanding the effects of seasonal burning on the dynamics of tallgrass prairie plants is important in formulating rational management, and conventional generalizations of how most species respond to season of fire may be misleading (Engle and Bidwell 2001). Thus, our objectives were to assess vegetation trends from an ongoing longterm study of annual burning in different seasons. Specific questions considered were: (1) What species are differentially affected by repeated autumn, winter, and spring fire, and does their response vary between topoedaphic sites? (2) How does species richness and diversity change in response to annual burning in different seasons? and (3) Are the purported adverse effects on biomass production from autumn and winter burning consistent across time and topographic positions?

\section{Materials and Methods}

\section{Study Area}

The study was conducted on Konza Prairie Biological Station, a 3,487-ha tall- grass prairie located in the Flint Hills of northeastern Kansas $\left(39^{\circ} 05^{\prime} \mathrm{N}, 96^{\circ} 35^{\prime} \mathrm{W}\right)$. This site is the largest tract of tallgrass prairie in the United States that is specifically managed for ecological research. To study how fire affects the structure and function of grassland vegetation, Konza Prairie is parceled into 52 watersheds that provide large replicated experimental units subjected to different fire regimes. Vegetation is typical of native tallgrass prairie and is dominated by warm-season perennial grasses, primarily big bluestem (Andropogon gerardii Vitman), indiangrass [Sorghastrum nutans (L.) Nash], and little bluestem [Schizachyrium scoparium (Michx.) Nash]. Forb species are widespread and constitute more than $75 \%$ of the species richness (Towne 2002).

The climate for the area is characterized by hot summers, cold winters, and moderately strong surface winds. Annual precipitation averages $859 \mathrm{~mm}$, with $75 \%$ of this occurring in the April to September growing season. Between 1994 and 2001, annual precipitation exceeded the long term average on 4 occasions, although rainfall during the growing season was above average in only 3 years (Fig. 1). The average frost-free season lasts 180 days.

Six watersheds that have not been grazed by cattle for more than 30 years were selected for a long-term seasonal burning study. The watersheds ranged in size from 11 to 39 ha and had been burned previously every 3 or 4 years in the spring

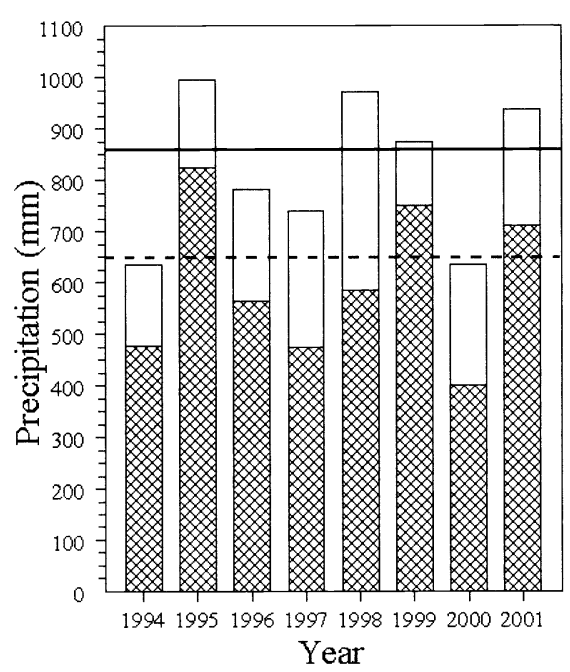

Fig. 1. Total annual precipitation and growing season (Apr-Sep) precipitation (lower hatched bar) for the years 1994-2001 at Konza Prairie. The solid horizontal line represents the 30 year annual precipitation mean. The dashed horizontal line represents the 30 year growing season precipitation mean. since 1972. Topographically, the watersheds are comprised of upland plateaus, rocky hillsides, and fertile lowlands. The upland topographic positions are relatively shallow, silty clay loams overlying limestone and shale layers (Udic Argiustolls, Florence series), whereas the lowland positions are deeper colluvial and alluvial deposits (Pachic Argiustolls, Tully series). Seasonal burning began in November 1993, when 2 watersheds were burned for the autumn treatment. Subsequent fire treatments included 2 watersheds that were burned in February 1994 and 2 in April 1994 for the winter and spring treatments, respectively. The same 2 watersheds were burned in the same season throughout the study. Average burn dates for the 8-year period were 26 November, 17 February, and 24 April. All burns were conducted under conditions of moderate wind speed and humidity, producing relatively intense head fires.

\section{Data Collection}

Species composition sampling began in 1994 after four, 50-m long transects, each with 5 permanent plots, were established on both upland and lowland topographic positions in all watersheds $(n=20$ plots for each topographic position). The canopy cover of every species in a $10-\mathrm{m}^{2}$ circular area around each plot was estimated and assigned to a percentage category (Bailey and Poulton 1968). Cover of individual species was determined by averaging the midpoint of the cover categories (i.e., $0.5,3,15,37.5,62.5,85$, and $97.5 \%$ ) across the 20 plots for each topographic position. We also calculated frequency of occurrence (the proportion of plots where an individual species occurred) as an alternative indication of how species respond to seasonal fire. All plots were surveyed each year in June and August.

Aboveground biomass production was measured at the end of each growing season by clipping 5 randomly selected quadrats $\left(0.1 \mathrm{~m}^{2}\right)$ adjacent to each plant composition transect $(\mathrm{n}=20$ plots per topographic position). Vegetation in the plots was clipped at ground level, separated into graminoid, forb, and woody components, oven-dried at $60^{\circ} \mathrm{C}$, and weighed.

\section{Data Analysis}

A total of 148 species were encountered in this study, but only those species with $>$ $2 \%$ mean canopy cover in any year or treatment were analyzed individually. Canopy cover of individual species and the summed cover of species in similar taxonomic and life-form groups (e.g., 
sedges, legumes, annual forbs, and woody species) were arcsine square-root transformed and analyzed as a split-split plot over time. The full model contained terms for burn season, topographic position, year, and their interactions. To evaluate patterns of change through time from seasonal burning, we used the annual deviation from the mean year value for the 8year study period as a linear covariate and the deviation squared as a quadratic covariate. We initially fit a full covariance model to each independent variable and the nonsignificant $(\mathrm{P}>0.05)$ effects were then deleted systematically. Inferences regarding trends through time were based on the respective regression coefficients. If a species response to season of fire differed between topographic positions, the regression slopes were tested for each site using appropriate contrasts. Otherwise, the response was combined across topographic positions and the slopes for each burn season compared. Linear and quadratic response curves were fitted using least square regression.

Aboveground biomass was analyzed as a split-split plot with burn season as the whole plot factor, topographic position as the subplot factor, and year as the sub-subplot factor. The effect of burn season was tested using the variation between replicate watersheds (nested within burn seasons) as the whole plot error term; topographic effects were tested using the topographic position $\mathrm{x}$ watershed (nested within burn season) mean square as the subplot error term; and year effects were tested with the residual mean square.

Species richness (the cumulative number of plant species detected in the 20 plots for each topographic position) and the Shannon diversity index $\left(H^{\prime}=\sum \mathrm{p}_{\mathrm{i}} \mathrm{x} \ln \right.$ $p_{i}$, where $p_{i}$ is the canopy cover of each species) were square-root transformed and analyzed using the split-split plot over time covariance model. Frequency values were arcsine square-root transformed and analyzed using the split-split plot model, with burn season as the whole-plot factor and topographic position and year as the split factors. We used SAS procedures (SAS Institute 1999) to analyze the data, with 0.05 as the probability level to establish statistical significance.

\section{Results and Discussion}

Topoedaphic factors influenced the response patterns of some species to repeated seasonal burning, although differences were primarily from variation in the
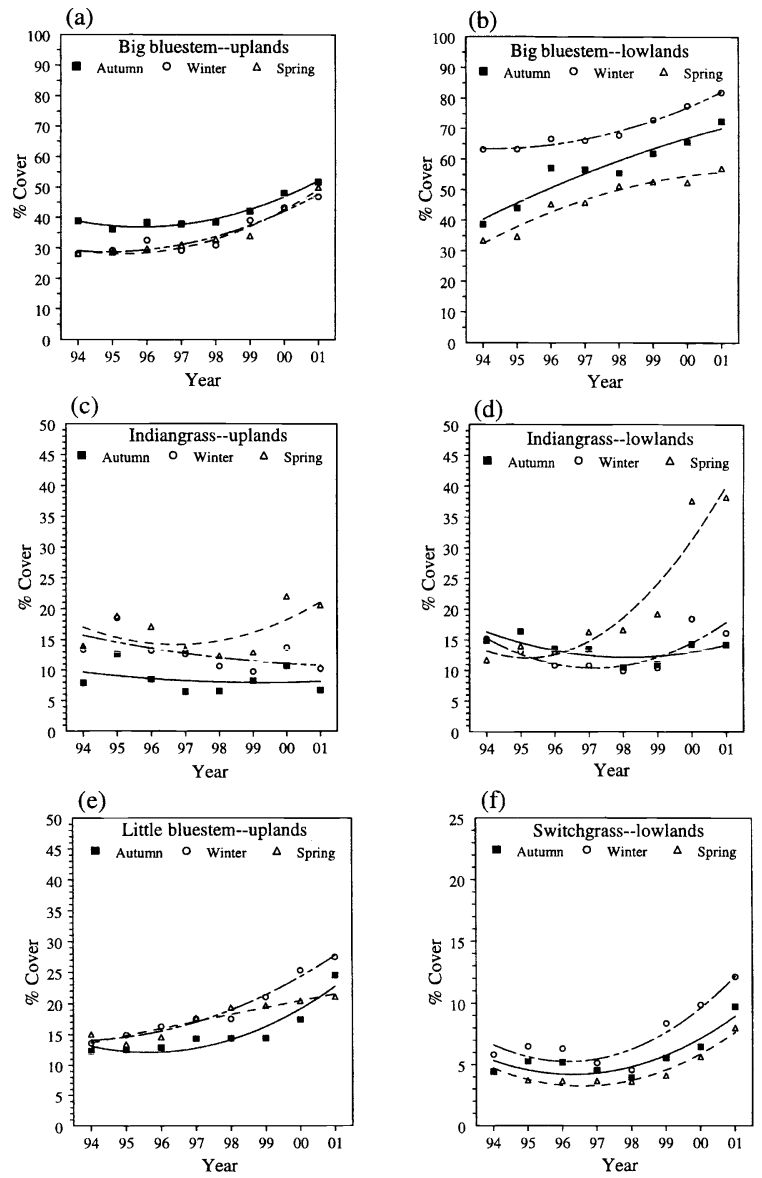

Fig. 2. Canopy cover changes through time in response to annual autumn, winter, and spring burning: (a, b) big bluestem on upland and lowland topographic locations, (c, d) indiangrass on upland and lowland topographic locations, (e) little bluestem on upland sites, and (d) switchgrass on lowland sites.

rate of change. In general, most species that responded to time of burning followed gradual curvilinear shifts through time. The quadratic downward trend exhibited by some species indicated sensitivity to fire, after which the population maintained its presence in the community at a lower level. In contrast, the concave temporal trend of some species indicated a negative short-term impact to fire, followed by a period where the species recovered to preexisting levels. The canopy cover of most species, however, remained stable through time, suggesting tolerance to annual burning in any season.

\section{Warm-season Grasses}

Burning in autumn and winter produced similar response patterns through time in all warm-season grass species. Big bluestem cover increased in response to annual burning in any season, although the changes through time were smaller on upland topographic positions (Fig. 2a) than on lowland positions (Fig. 2b). Indiangrass increased only with spring burning, and exhibited the largest response of any warm-season grass to fire. However, it required 7 consecutive burns before the upturn, with the greatest increase occurring on lowland topographic sites (Fig. 2c, 2d). Little bluestem cover increased on upland locations with autumn and winter burning, but did not change (P $=0.13$ ) in response to spring burning (Fig. 2e). On lowland sites, little bluestem cover remained stable through time with all burn treatments (Table 1). Switchgrass (Panicum virgatum $\mathrm{L}$.) increased in response to fire in any season on lowland sites (Fig. 2f); but on upland sites, switchgrass cover did not change significantly through time with any burn treatment (Table 1).

The collective canopy cover of all warm-season grasses increased from burning in any season, although the rate of change differed between topographic positions. On upland sites, the increases through time were similar for all burn sea- 
Table 1. Average percent cover of graminoid species after 8 years of annual burning in different seasons on upland and lowland topographic positions. A positive superscript indicates cover increased $(P<0.05)$ from 1994. A negative superscript indicates cover declined significantly from 1994.

\begin{tabular}{|c|c|c|c|c|c|c|}
\hline \multirow[b]{2}{*}{ Species } & \multicolumn{3}{|c|}{ Uplands } & \multicolumn{3}{|c|}{ Lowlands } \\
\hline & $\overline{\text { Autumn }}$ & Winter & Spring & $\overline{\text { Autumn }}$ & Winter & Spring \\
\hline & & $-(\%)$ & & & $-(\%)$ & $\cdots$ \\
\hline Andropogon gerardii & $51.7^{+}$ & $46.9^{+}$ & $49.9^{+}$ & $72.4^{+}$ & $81.9^{+}$ & $57.0^{+}$ \\
\hline Bouteloua curtipendula & 3.5 & 2.6 & $3.0^{-}$ & 0.1 & 0.2 & $0.2^{-}$ \\
\hline Panicum virgatum & 1.8 & 2.3 & 4.8 & $9.7^{+}$ & $12.1^{+}$ & $8.0^{+}$ \\
\hline Schizachyrium scoparium & $24.6^{+}$ & $27.5^{+}$ & 21.1 & 13.4 & 2.5 & 14.4 \\
\hline Sorghastrum nutans & 6.7 & 10.2 & $20.6^{+}$ & 14.2 & 16.1 & $38.2^{+}$ \\
\hline Sporobolus compositus & $0.8^{-}$ & $2.0^{-}$ & $0.9^{-}$ & $4.8^{-}$ & $2.5^{-}$ & $0.9^{-}$ \\
\hline Sporobolus heterolepis & $3.7^{+}$ & $1.7^{+}$ & 1.7 & 0.1 & 0.6 & 1.1 \\
\hline All warm-season grasses & $93.1^{+}$ & $93.7^{+}$ & $102.4^{+}$ & $114.7^{+}$ & $115.9^{+}$ & $120.7^{+}$ \\
\hline Carex spp. & $17.5^{+}$ & $17.1^{+}$ & $1.4^{-}$ & $15.8^{+}$ & $11.6^{+}$ & $4.9^{-}$ \\
\hline Dichanthelium oligosanthes & 2.9 & 8.3 & $1.0^{-}$ & 1.4 & 1.2 & $0.7^{-}$ \\
\hline Koeleria macrantha & $9.3^{+}$ & 2.7 & 0.2 & $<0.1$ & $<0.1$ & $<0.1$ \\
\hline Poa pratensis & $0.1^{-}$ & $0.1^{-}$ & $0.1^{-}$ & $0.3^{-}$ & $0.4^{-}$ & $0.1^{-}$ \\
\hline All cool-season graminoids & $30.2^{+}$ & $28.3^{+}$ & $2.6^{-}$ & 17.9 & 13.3 & $6.8^{-}$ \\
\hline
\end{tabular}

sons (Fig. 3a); but on lowland sites, spring burning produced the greatest increase in erated or benefitted from annual burning. Tall dropseed [Sporobolus compositus (Poir.) Merr.] decreased in response to fire in any season (Table 1). Cover of side-oats grama [Bouteloua curtipendula (Michx.) Torr.] also was reduced with spring burning, but not from autumn or winter burning (Table 1).

\section{Cool-season Graminoids}

Prairie junegrass [Koeleria macrantha (Ledeb.) Schult.], a species predominant on upland sites, increased linearly in response to autumn burning, but remained stable through time with winter and spring burning (Fig. 3c). All other cool-season graminoids declined significantly with repeated spring burning, whereas Kentucky bluegrass (Poa pratensis L.) was the only cool-season species that declined in response to autumn and winter burning (Table 1). On upland sites, Scribner's panicum [Dichanthelium
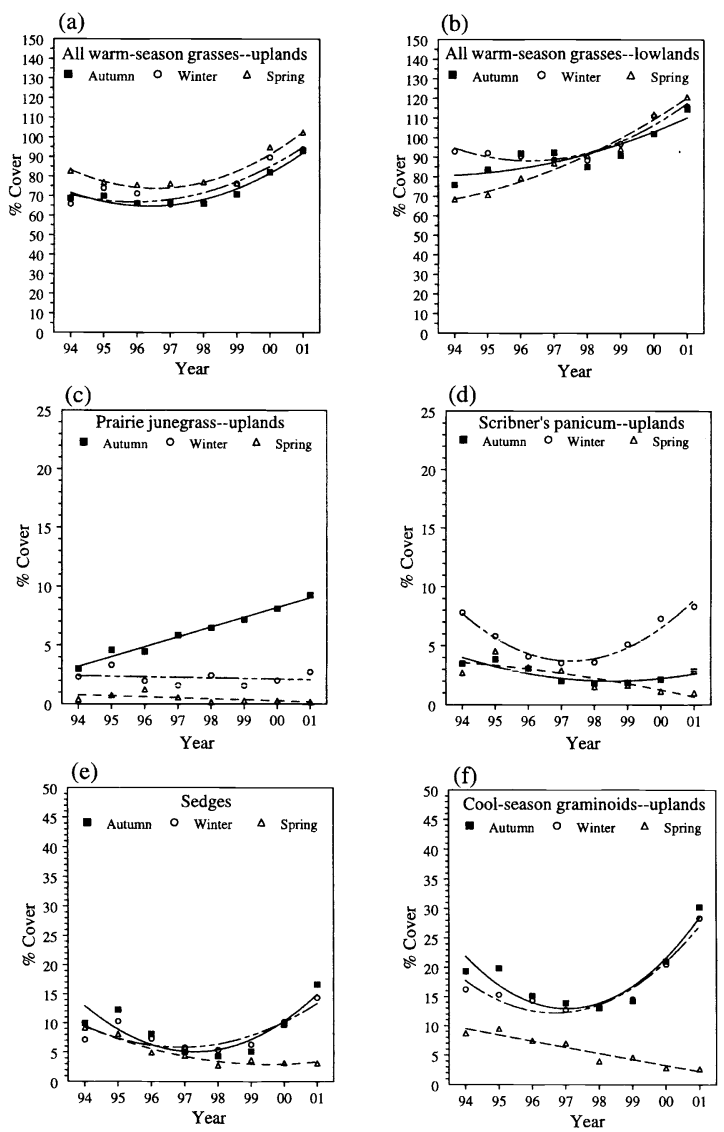

Fig. 3. Canopy cover changes through time in response to annual autumn, winter, and spring burning: $(a, b)$ total cover of all warmseason grass species on upland and lowland topographic locations, (c) prairie junegrass on upland sites, (d) Scribner's panicum on upland sites, (e) sedges for both topographic sites combined, and (f) total cover of all cool-season graminoids on upland sites.
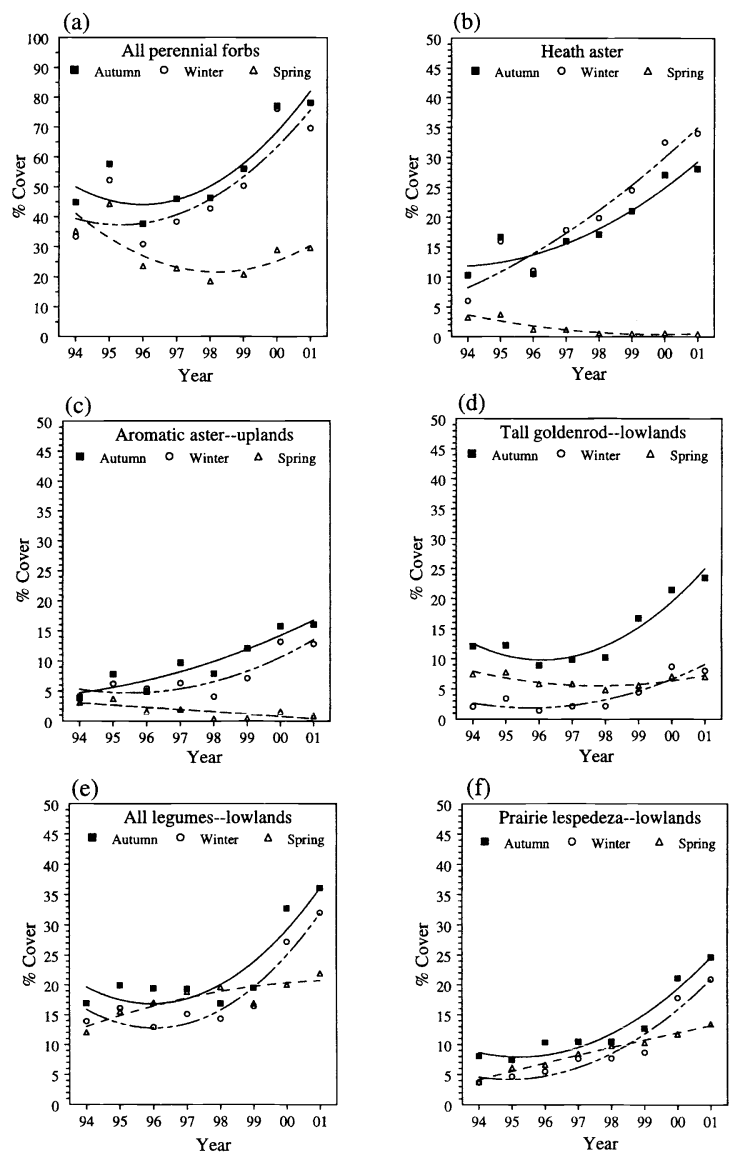

Fig. 4. Canopy cover changes through time in response to annual autumn, winter, and spring burning for various perennial forbs on different topographic positions: (a) total cover of all perennial forbs for both topographic sites combined, (b) heath aster for both topographic sites combined, (c) aromatic aster on upland sites, (d) tall goldenrod on lowland sites, (d) total cover of all legume species on lowland sites, and (f) prairie lespedeza on lowland sites. 
Table 2. Average percent cover of various forb species after 8 years of annual burning in different seasons on upland and lowland topographic positions. A positive superscript indicates cover increased $(P<0.05)$ from 1994. A negative superscript indicates cover declined significantly from 1994.

\begin{tabular}{|c|c|c|c|c|c|c|}
\hline \multirow[b]{2}{*}{ Species } & \multicolumn{3}{|c|}{ Uplands } & \multicolumn{3}{|c|}{ Lowlands } \\
\hline & Autumn & Winter & Spring & Autumn & Winter & Spring \\
\hline & \multicolumn{3}{|c|}{ - } & \multicolumn{3}{|c|}{ - (\%) - - - - } \\
\hline Ambrosia psilostachya & 2.0 & 1.3 & 0.7 & 1.4 & 1.5 & 1.6 \\
\hline Artemisia ludoviciana & $0.2^{-}$ & $0.7^{-}$ & $<0.1^{-}$ & 1.4 & 0.3 & $<0.1^{-}$ \\
\hline Brickellia eupatorioides & 0.8 & 1.0 & $0.8^{-}$ & 0.5 & 0.1 & 0.5 \\
\hline Physalis pumila & 0.5 & $0.4^{-}$ & 0.5 & $0.6^{-}$ & $0.5^{-}$ & $0.7^{-}$ \\
\hline Ruellia humilis & $0.3^{-}$ & $0.4^{-}$ & 0.4 & $0.5^{-}$ & $0.4^{-}$ & 2.3 \\
\hline Salvia azurea & $5.8^{+}$ & 4.0 & 5.7 & 0.1 & $<0.1$ & 0 \\
\hline Solidago canadensis & 0 & 0 & 0 & $23.5^{+}$ & $8.0^{+}$ & 7.0 \\
\hline Solidago missouriensis & 0.3 & $0.4^{-}$ & $0.4^{-}$ & 0.4 & 1.8 & 3.0 \\
\hline Symphyotrichum ericoides & $17.9^{+}$ & $23.1^{+}$ & $0.5^{-}$ & $38.3^{+}$ & $44.9^{+}$ & $0.4^{-}$ \\
\hline Symphyotrichum oblongifolium & $16.0^{+}$ & $12.8^{+}$ & $0.9^{-}$ & 0 & 0 & 0 \\
\hline All perennial forbs & $51.9^{+}$ & $51.8^{+}$ & 16.1 & $104.4^{+}$ & $87.4^{+}$ & 43.1 \\
\hline Amorpha canescens & 2.8 & 0.4 & 3.3 & 3.8 & 4.9 & 5.5 \\
\hline Dalea canadia & 0.2 & 0.7 & 0.1 & $2.0^{+}$ & 1.7 & 0.8 \\
\hline Lespedeza capitata & 0.2 & 0.7 & 0.1 & $2.3^{+}$ & 2.3 & 1.3 \\
\hline Lespedeza violaceae & $<0.1$ & $<0.1$ & $<0.1$ & $24.6^{+}$ & $20.9^{+}$ & $13.4^{+}$ \\
\hline All legume species & 7.3 & 5.4 & 6.3 & $36.1+$ & $32.0^{+}$ & $21.9^{+}$ \\
\hline All annual forbs & 0.2 & 0.1 & 0.2 & 0.3 & 0.2 & 0.7 \\
\hline All woody species & 0.2 & 0.2 & 0.7 & 0.8 & 2.2 & 1.6 \\
\hline
\end{tabular}

oligosanthes (Nash) Gould], the most common cool-season grass on Konza Prairie, declined and then recovered to beginning levels in response to winter burning (Fig. 3d); but on lowland sites, the temporal patterns remained stable with both winter and autumn burning (Table 1). Sedges [primarily Carex inops Bailey, $C$. meadii Dewey, C. brevior (Dewey) Mack., and Cyperus lupulinus (Spreng.) Marcks] also declined initially in response to both autumn and winter burning before diverging upward and attaining the highest cover values after 8 years of fire (Fig. 3e). The collective cover of all cool-season graminoids followed concave patterns through time with autumn and winter burning. Although the trends were similar on both topographic positions, cool-season graminoid cover eventually surpassed initial values on upland sites (Fig. 3f), but only recovered to the original levels on lowland sites (Table 1). The transitory decline of most cool-season graminoid species in response to autumn and winter burning coincided with 3 consecutive years of below normal precipitation during the growing season, suggesting that moisture availability may be crucial in mediating their response patterns to seasonal fire.

\section{Perennial Forbs}

The combined cover of all perennial forbs responded with similar curvilinear upward trends in response to autumn and winter burning, but did not change through time with spring burning (Fig. 4a). Species that were primarily responsible for the increase in forb cover from repeated autumn and winter burning were heath aster [Symphyotrichum ericoides (L.) Nesom], aromatic aster [S. oblongifolium (Nutt.) Nesom], and tall goldenrod (Solidago canadensis L.) (Figs. 4b-4d). Western ragweed (Ambrosia psilostachya DC), a dominant forb in tallgrass prairie, was not affected $(\mathrm{P}>0.10)$ by time of burning on either topographic position (Table 2). However, dynamic interannual fluctuations in western ragweed cover suggest that factors other than season of burn influenced temporal patterns. Although burning in autumn or early-spring will putatively increase forbs or "weedy" species (Anderson 1961, Anderson et al. 1970, Schwegman and McClain 1985), it required repeated burning in autumn or winter before forb canopy cover eventually increased.

Total legume cover increased on lowland sites in response to burning in any season, but the greatest changes through time occurred with autumn and winter burning (Fig. 4e). Prairie lespedeza [Lespedeza violaceae (L.) Pers.], a species occurring predominantly on lowland sites, exhibited the most prominent increase of all legumes to annual burning, and was the only forb species that increased with spring burning (Fig. 4f). Cover of leadplant (Amorpha canescens Pursh), the

Table 3. Average percent frequency of species that changed significantly after 8 years of annual burning in different seasons on upland and lowland topographic positions $\left(10-\mathrm{m}^{2}\right.$ plots; $\left.n=40\right)$. A positive superscript indicates the frequency of occurrence increased $(P<0.05)$ from 1994 . A negative superscript indicates the frequency declined significantly from 1994.

\begin{tabular}{|c|c|c|c|c|c|c|}
\hline \multirow[b]{2}{*}{ Species } & \multicolumn{3}{|c|}{ Uplands } & \multicolumn{3}{|c|}{ Lowlands } \\
\hline & Autumn & Winter & Spring & Autumn & Winter & Spring \\
\hline Grasses: & \multicolumn{3}{|c|}{$\ldots \ldots(\%) \ldots \ldots$} & \multicolumn{3}{|c|}{$\ldots \ldots \ldots(\%)-\ldots \ldots$} \\
\hline Bouteloua curtipendula & 77.5 & $97.5^{+}$ & 100 & 17.5 & $37.5^{+}$ & 30.0 \\
\hline Bouteloua gracilis & $22.5^{+}$ & 30.0 & $32.5^{+}$ & 0 & 0 & 0 \\
\hline Dichanthelium acuminatum & 5.0 & 0 & 7.5 & 27.5 & $15.0^{+}$ & $42.5^{+}$ \\
\hline Dichanthelium oligosanthes & 100 & 100 & $100^{+}$ & $90.0^{+}$ & 92.5 & $100^{+}$ \\
\hline Eragrostis spectabilis & 7.5 & 30.0 & 27.5 & 7.5 & 7.5 & $75.0^{+}$ \\
\hline Schizachyrium scoparium & 87.5 & 95.0 & 95.0 & $92.5^{+}$ & 72.5 & $95.0^{+}$ \\
\hline Sporobolus compositus & 85.0 & $95.0^{+}$ & 75.0 & 97.5 & $97.5^{+}$ & 90.0 \\
\hline Poa pratensis & $15.0^{-}$ & $32.5^{-}$ & $15.0^{-}$ & $62.5^{-}$ & 45.0 & $22.5^{-}$ \\
\hline \multicolumn{7}{|l|}{ Forbs: } \\
\hline Asclepias verticillata & 32.5 & 42.5 & 27.5 & 25.0 & $15.0^{-}$ & $77.5^{+}$ \\
\hline Asclepias viridis & $20.0^{-}$ & 35.0 & 35.0 & 37.5 & $22.5^{-}$ & $70.0^{+}$ \\
\hline Artemisia ludoviciana & 35.0 & 67.5 & $15.0^{-}$ & 40.0 & 32.5 & $7.5^{-}$ \\
\hline Cirsium altissimum & 2.5 & 0 & 0 & $35.0^{-}$ & 20.0 & $15.0^{-}$ \\
\hline Dalea candida & $27.5^{+}$ & $37.5^{+}$ & $22.5^{+}$ & $75.0^{+}$ & $80.0^{+}$ & $72.5^{+}$ \\
\hline Dalea purpurea & $65.0^{+}$ & $52.5^{+}$ & $70.0^{+}$ & 15.0 & $35.0^{+}$ & 0 \\
\hline Lespedeza capitata & $32.5^{+}$ & $32.5^{+}$ & 17.5 & $67.5^{+}$ & $60.0^{+}$ & $67.5^{+}$ \\
\hline Lespedeza violacea & 2.5 & 2.5 & 2.5 & $82.5^{+}$ & $85.0^{+}$ & $57.5^{+}$ \\
\hline Oxalis stricta & 15.0 & 2.5 & $0^{-}$ & 5.0 & 2.5 & 42.5 \\
\hline Oxalis violacea & 0 & 2.5 & 2.5 & 82.5 & 52.5 & $80.0^{+}$ \\
\hline Physalis pumila & 47.5 & 42.5 & $52.5^{+}$ & $70.0^{+}$ & 85.0 & $92.5^{+}$ \\
\hline Ruellia humilis & $67.5^{+}$ & $72.5^{+}$ & 65.0 & 82.5 & 75.0 & 87.5 \\
\hline Solidago canadensis & 0 & 0 & 0 & 55.0 & $55.0^{+}$ & 52.5 \\
\hline Solidago missouriensis & 27.5 & 47.5 & 37.5 & 37.5 & 35.0 & $52.5^{+}$ \\
\hline Vernonia baldwinii & 55.0 & 67.5 & 40.0 & 67.5 & $70.0^{+}$ & 60.0 \\
\hline
\end{tabular}


most common legume species on Konza Prairie, did not change significantly on either topographic position after 8 years of burning in any season (Table 2). Densities of many legume species are higher in tallgrass prairie burned annually in the spring than in prairie that is not burned (Towne and Knapp 1996). Trends in canopy cover, however, suggest that most legume species tolerate annual spring fire rather than benefit directly from it.

\section{Annual Species}

Annual forb species were too sparse to analyze individually, but the combined canopy cover of all annual forbs did not change through time with any burn treatment (Table 2). Collectively, annual forbs averaged $0.6 \%$ cover the first 2 years of burning, after which levels dropped and stabilized in all burn treatments. In contrast, extremely low levels of 2 annual grass species [common witchgrass (Panicum capillare L.) and little barley (Hordeum pusillum Nutt.)] were detected in the first 2 years of the study, but subsequently disappeared and never reappeared in any burn treatment.

Annual plants are potentially susceptible to fire, but some forb species [e.g., daisy fleabane (Erigeron strigosus Muhl. ex Willd.) and grooved flax (Linum sulcatum Riddell)] persisted under all burn regimes. A few annual species [e.g., annual ragweed (Ambrosia artemisiifolia L.), snow-on-themountain (Euphorbia marginata Pursh), common pepperweed (Lepidium densiflorum Schrad.), and smooth-seed wildbean (Strophostyles leiosperma (Torr. \& A. Gray) Piper)] appeared sporadically in some years. However, most other annual forb species [e.g., rough false-penny-royal (Hedeoma hispida Pursh), prickly lettuce (Lactuca serriola L.), red-seed plantain (Plantago rhodosperma Decne.), clasping Venus'-looking-glass [Triodanis perfoliata (L.) Nieuwl.], and field pansy (Viola bicolor Pursh)] disappeared after the second burn and never reappeared, indicating intolerance to fire in any season.

\section{Woody Species}

Woody shrubs [e.g., rough-leaf dogwood (Cornus drummondii Mey.), smooth sumac (Rhus glabra L.), New Jersey tea (Ceanothus herbaceous Raf.), buckbrush (Symphoricarpos orbiculatus Moench), and Arkansas rose (Rosa arkansana Porter)] also occurred too sporadically to analyze individually. Average canopy cover of all woody species (excluding leadplant) did not change significantly through time in any burn treatment (Table 2). In ungrazed tall-
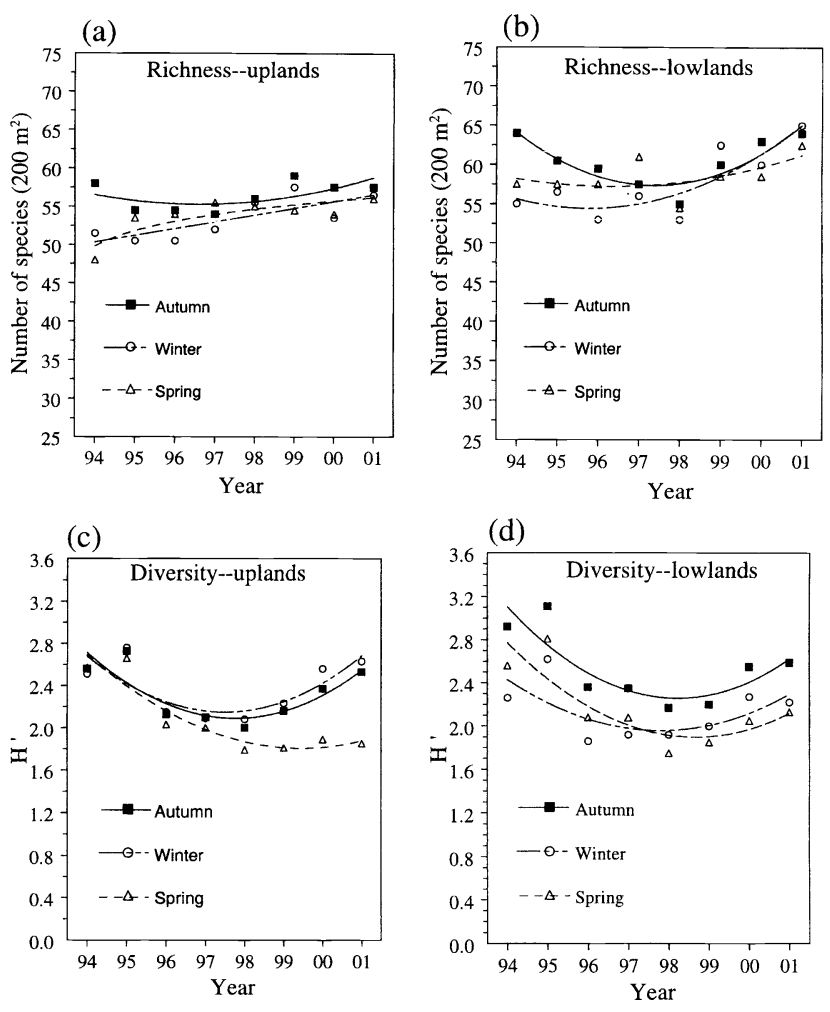

Fig 5. Changes in diversity indices through time in response to annual autumn, winter, and spring burning on different topographic positions: (a, b) species richness for upland and lowland topographic positions, $(\mathrm{c}, \mathrm{d})$ the Shannon diversity index for upland and lowland topographic positions.

grass prairie, woody species are controlled with fire (Adams et al. 1982, Hulbert 1986), and the lack of a significant change of woody cover in this study is likely due to low initial levels. Although annual fire suppresses canopy cover of woody species by removing accumulated top growth, 8 years of burning in autumn, winter, or spring did not eliminate any shrub species.

\section{Frequency of Occurrence}

Depending upon topographic position, burning in any season increased the frequencies of 4 species [prairie lespedeza, round-head lespedeza (Lespedeza capitata Michx.), white prairie-clover (Dalea candida Willd.), and purple prairie-clover (Dalea purpurea Vent.)] (Table 3). Eight years of spring burning increased the frequency of occurrence in 15 species, compared with 10 species increasing from winter burning and 9 species increasing in response to autumn burning.

Changes in the frequency of occurrence were not always associated with concomitant changes in canopy cover. For example, the frequency of some species [white prairie-clover, purple prairie-clover, round-head lespedeza, and fringe-leaf ruellia (Ruellia humilis)] increased significantly in response to different burning regimes without an accompanying change in canopy cover. This suggests that burning may be important in the colonization of these species, but their density or stature is sufficiently low that changes in canopy cover are not detectable.

\section{Diversity Indices}

Species richness increased in response to spring and winter burning, but declined and then recovered to initial levels with autumn burning on both topographic positions (Fig. 5a, 5b). After 8 years of annual fire, however, the number of species on either topographic position was similar for all burn seasons. In tallgrass prairie, species richness declines as fire frequency increases (Collins et al. 1995). The trends in species richness observed in this study, however, indicated the eventual downturn requires more than 8 consecutive burns.

The effect of seasonal burning on the Shannon diversity index varied with topographic position. On upland sites, diversity declined progressively in response to annual spring burning, and declined but then recovered with both autumn and win- 

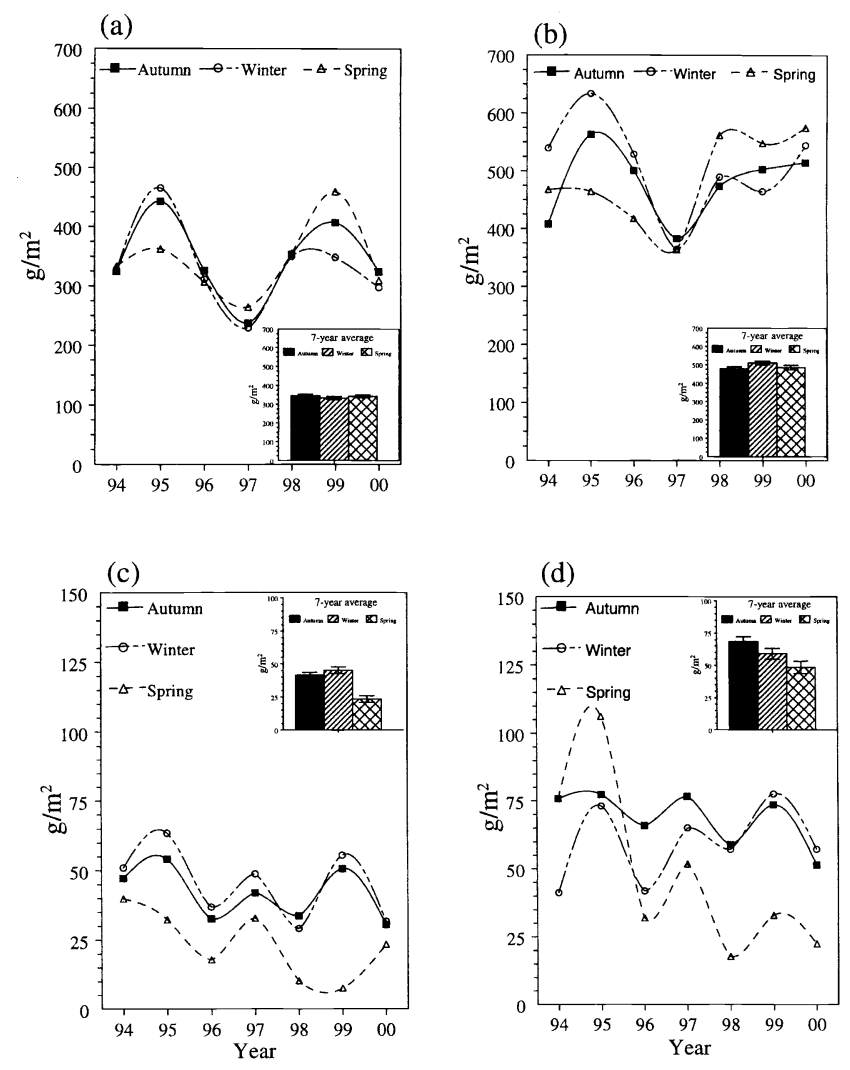

Fig. 6. Changes in biomass production in response to annual autumn, winter, and spring burning on different topographic positions: (a, b) grass biomass on upland and lowland sites, $(c, d)$ forb biomass on upland and lowland sites. Inset in each graph represents the 7 year mean $( \pm \mathrm{SE})$.

ter burning (Fig. 5c). On lowland sites, however, diversity decreased in response to both spring and autumn burning, and did not change through time with winter burning (Fig 5d).

\section{Biomass}

The effect of burn season on grass biomass varied inconsistently through time. Compared to spring burning, autumn fire never reduced $(\mathrm{P}>0.10)$ grass biomass on upland sites (Fig. 6a), and winter burning reduced grass production only once $(24 \%$ in 1999). In contrast, autumn and winter burning increased grass biomass $22 \%$ and $28 \%$, respectively above spring burning on upland locations in 1995. On lowland sites, spring burning produced significantly higher grass biomass than autumn burning only in 1998, and produced more biomass than winter burning only in 1998 and 1999 (Fig. 6b). Average grass production did not differ $(\mathrm{P}>0.80)$ among burn seasons on either uplands (Fig. 6a inset) or lowlands (Fig. 6b inset). Average forb biomass also was not different $(\mathrm{P}>0.30)$ among burn seasons, although production was usually lowest in response to spring burning on both topographic positions (Figs. 6c and 6d). Woody biomass averaged $<2 \mathrm{~g} / \mathrm{m}^{2}$ on uplands and $<7 \mathrm{~g} / \mathrm{m}^{2}$ on lowlands, and did not differ $(\mathrm{P}>0.78)$ among burn treatments.

Interactions among burn seasons, topographic positions, and years suggest that biomass production was likely mediated by soil moisture availability. Burning tallgrass prairie during winter or early spring is traditionally denounced because bare ground that is exposed for extended periods could potentially increase surface runoff and evaporation losses, thereby lowering soil moisture and subsequent biomass production (Hanks and Anderson 1957, Bieber and Anderson 1961, Anderson 1965, McMurphy and Anderson 1965, Owensby and Anderson 1967). Precipitation during the growing season was below normal in 5 years of this study, and if early-season burning unequivocally reduced grass biomass, it should have been apparent under these droughty condi- tions, particularly on the xeric uplands. Consequently, paradigms of reduced grass production from autumn or winter burning may be anomalous events from inopportune precipitation patterns, site-specific occurrences, artifacts from inadequate sampling, or confounded with livestock grazing; but they are not axiomatic for the Kansas Flint Hills.

\section{Summary and Implications}

The changes in vegetation due to repeated seasonal burning documented in this study occurred in ungrazed prairie where fire uniformly consumes the area. Response patterns may differ in grazed prairie because grazing produces a patchy burned landscape that creates numerous protective niches for species sensitive to fire. Thus, grazing can interact with seasonal burning to increase species richness and diversity (Coppedge et al. 1998). The mosaic burn patterns in grazed prairie will additionally buffer trends of many species to seasonal fire. Objectives for utilizing fire season as a management tool may vary between grazed and ungrazed prairie, but annual burning of ungrazed prairie at times other than late spring is apparently a sustainable option that does not degrade the integrity of tallgrass prairie.

Our findings contrast with many of the conventional views of how tallgrass prairie vegetation responds to seasonal fire and challenges traditional recommendations that burning should only occur in late spring. Based on these data, current decisions on managing tallgrass prairie that is burned at times other than late spring needs to be objectively reevaluated. Opposition to autumn, winter, or early spring burning is primarily an indoctrinated tenet from anti-burn campaigns in earlier decades (Hoy and Isern 1995) and inferences extrapolated from other ecosystems (Wright and Bailey 1980). In addition, fire season is often mistakenly blamed for the adverse effects from concentrated livestock grazing in pastures that have been partially burned by wildfires (Engle and Bidwell 2001). Tallgrass prairie is resilient to change, and although cover of some indigenous perennial forb species eventually increased in response to autumn and winter burning, that effect required repeated fire and did not come at the expense of warm-season grasses. 


\section{Literature Cited}

Abrams, M. D. and L. C. Hulbert. 1987. Effect of topographic position and fire on species composition in tallgrass prairie in northeast Kansas. Amer. Midl. Natur. 117:442-445.

Adams, D. E. and R. C. Anderson. 1978. The response of a central Oklahoma grassland to burning. Southwest. Natur. 23:623-632.

Adams, D. E., R. C. Anderson, and S. L. Collins. 1982. Differential response of woody and herbaceous species to summer and winter burning in an Oklahoma grassland. Southwest. Natur. 27:55-61.

Aldous, A. E. 1934. Effect of burning on Kansas bluestem pastures. Kansas Agr. Exp. Sta. Bull. 38.

Anderson, K. L. 1961. Burning bluestem ranges. Crops and Soils 13:13-14.

Anderson, K. L. 1965. Time of burning as it affects soil moisture in an ordinary upland bluestem prairie in the flint hills. J. Range Manage. 18:311-316.

Anderson, K. L., E. F. Smith, and C. E. Owensby. 1970. Burning bluestem range. J. Range Manage. 23:81-92.

Axelrod, D. I. 1985. Rise of the grassland biome, central North America. Bot. Rev. 51:163-201.

Bailey, A. W. and C. E. Poulton. 1968. Plant communities and environmental interrelationships in a portion of the Tillamook Burn, northwestern Oregon. Ecol. 49:1-13.

Bieber, G. L. and K. L. Anderson. 1961. Soil moisture in bluestem grassland following burning. J. Soil and Water Conserv. 16:186-187.

Bragg, T. B. 1982. Seasonal variations in fuel and fuel consumption by fires in a bluestem prairie. Ecol. 63:7-11.

Catlin, G. 1973. Letters and notes on the manners, customs, and conditions of the North American Indians. Dover Publications, Inc., New York, N.Y.

Collins, S. L. 1992. Fire frequency and community heterogeneity in tallgrass prairie vegetation. Ecol. 73:2001-2006.

Collins, S. L., S. M. Glenn, and D. J. Gibson. 1995. Experimental analysis of intermediate disturbance and initial floristic composition: decoupling cause and effect. Ecol. 76:486-492.

Coppedge, B. R., D. M. Engle, C. S. Toepfer, and J. H. Shaw. 1998. Effects of seasonal fire, bison grazing and climatic variation on tallgrass prairie vegetation. Plant Ecol. 139:235-246

Engle, D. M. and T. G. Bidwell. 2001. Viewpoint: the response of central North American prairies to seasonal fire. J. Range Manage. 54:2-10.

Gibson, D. J. 1988. Regeneration and fluctuation of tallgrass prairie vegetation in response to burning frequency. Bull. Torrey Bot. Club 115:1-12.

Gibson, D. J. and L. C. Hulbert. 1987. Effects of fire, topography and year-to-year climatic variation on species composition in tallgrass prairie. Vegetatio 72:175-185.
Hanks, R. J. and K. L. Anderson. 1957. Pasture burning and moisture conservation. J. Soil and Water Conserv. 12:228-229.

Hoy, J. 1989. Controlled pasture burning in the folklife of the Kansas flint hills. Great Plains Quart. 9:231-238.

Hoy, J. F. and T. D. Isern. 1995. Bluestem and tussock: fire and pastoralism in the flint hills of Kansas and the tussock grasslands of New Zealand. Great Plains Quart. 15:169-184.

Hulbert, L. C. 1986. Fire effects on tallgrass prairie. Proc. Ninth No. Amer. Prairie Conf. 9:138-142.

Isern, T. D. 1985. Farmers, ranchers, and stockmen of the flint hills. Western Historical Quart. 16:253-264.

Kelting, R. W. 1957. Winter burning in central Oklahoma grassland. Ecol. 38:520-522.

Kimmerer, R. W. and F. K. Lake. 2001. The role of indigenous burning in land management. J. Forestry 99:36-41.

Kollmorgen, W. M. and D. S. Simonett. 1965. Grazing operations in the flint hillsbluestem pastures of Chase County, Kansas. Ann. Assoc. Amer. Geog. 55:260-290.

Lovell, D. L., R. A. Henderson, and E. A. Howell. 1982. The response of forb species to seasonal timing of prescribed burns in remnant Wisconsin prairies. Proc. Eighth No. Amer. Prairie Conf. 8:11-15.

McClain, W. E. and S. L. Elzinga. 1994. The occurrence of prairie and forest fires in Illinois and other midwestern states, 1679 to 1854. Erigenia 13:79-90.

McMurphy, W. E. and K. L. Anderson. 1963. Burning bluestem range--forage yields. Trans. Kansas Acad. Sci. 66: 49-51.

McMurphy, W. E. and K. L. Anderson. 1965. Burning flint hills range. J. Range Manage. 18:265-269.

Owensby, C. E. and K. L. Anderson. 1967. Yield responses to time of burning in the Kansas flint hills. J. Range Manage. 20:12-16.

Penfound, W. T. and R. W. Kelting. 1950. Some effects of winter burning on a moderately grazed pasture. Ecol. 31:554-560.

Pyne, S. J. 1982. Fire in America. A cultural history of wildland and rural fire. Princeton University Press, Princeton, N.J.

SAS Institute. 1999. SAS system for windows, version 8.01. SAS Institute, Cary, N.C.

Sauer, C. O. 1944. A geographic sketch of early man in America. Geog. Rev. 34:529-573.

Schwegman, J. E. and W. E. McClain. 1985. Vegetative effects and management implications of a fall prescribed burn on an Illinois hill prairie. Natural Areas J. 5:4-8.

Stewart, O. C. 1951. Burning and natural vegetation in the United States. Geog. Rev. 41:317-320.

Towne, E. G. 2002. Vascular plants of Konza Prairie Biological Station: an annotated checklist of species in a Kansas tallgrass prairie. Sida 20:269-294.

Towne, E. G. and A. K. Knapp. 1996. Biomass and density responses in tallgrass prairie legumes to annual fire and topographic position. Amer. J. Bot. 83:175-179.
Towne, G. and C. Owensby. 1984. Long-term effects of annual burning at different dates in ungrazed Kansas tallgrass prairie. J. Range Manage. 37:392-397.

Woodcock, D. W. and P. V. Wells. 1994. The burning of the new world: the extent and significance of broadcast burning by early humans. Chemosphere 29:935-948.

Wright, H. A. and A. W. Bailey. 1980. Fire ecology and prescribed burning in the Great Plains-a research review. USDA General Tech. Rep. INT-77. 